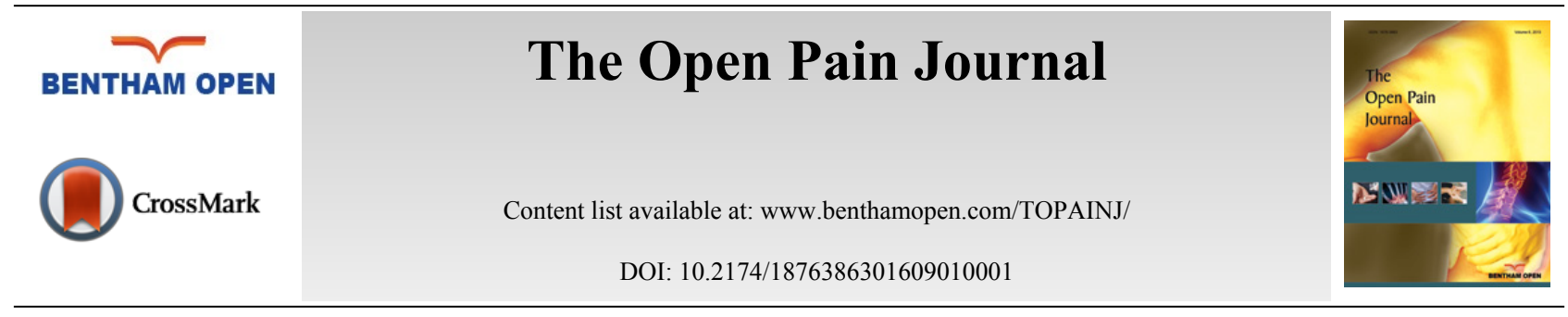

\title{
Changes in Spinal Cord Following Inflammatory and Neuropathic Pain and the Effectiveness of Resiniferatoxin
}

\author{
Mruvil Abooj, Mahendra Bishnoi ${ }^{*}$, Christine A. Bosgraaf and Louis S. Premkumar \\ Department of Pharmacology, Southern Illinois University School of Medicine, Springfield, IL-62702, USA
}

\begin{abstract}
Peripheral inflammation or nerve injury results in changes in the spinal cord, initiating a process of central sensitization. Although nociceptive Transient Receptor Potential (TRP) channels have been studied extensively, the role of these channels expressed at the central terminals in the spinal cord is not fully understood. Here, we studied the expression and function of TRPV1 channels at the spinal cord following induction of inflammatory pain by Complete Freund's Adjuvant (CFA) and neuropathic pain by Chronic Constriction Injury (CCI). Rats treated with CFA or subjected to CCI developed long-term thermal and mechanical hypersensitivity. Peripheral inflammation or injury induced an inflammatory response at the levels of spinal cord, which included activation of glia and increased levels of proinflammatory mediators. As a result, expression of TRPV1 was significantly increased and the associated function of TRPV1-mediated CGRP release was also significantly increased. Single intrathecal administration of resiniferatoxin (RTX), an ultrapotent TRPV1 agonist, selectively reversed inflammatory thermal hypersensitivity and the associated changes in TRPV1 expression and function without affecting mechanical hypersensitivity. In summary, peripheral nerve activity triggers an inflammatory response at the spinal dorsal horn, which results in enhanced expression and function of TRPV1 channels. Targeting TRPV1 expressed in the central terminals is a viable strategy to alleviate certain modalities of pain.
\end{abstract}

Keywords: CGRP, inflammatory, neuropathic, resiniferatoxin, TRPV1.

\section{INTRODUCTION}

Inflammatory and neuropathic pain is a symptom of several pathologies, including but not limited to arthritis, cancer and diabetes. Irrespective of the underlying pathology, the signs and symptoms are often the same: spontaneous pain, hyperalgesia, allodynia and pain summation. Peripheral injury-induced neuronal activity results in an inflammatory response at the spinal cord, which includes release of Calcitonin Gene-Related Peptide (CGRP) and Substance P (SP) from presynaptic nerve terminals and activation of glia influencing the synthesis and release of TRPV1 agonist anandamide and pro and anti-inflammatory mediators. Anandamide and inflammatory mediators act retrogradely to modulate synaptic transmission and TRPV1 expression and function, respectively. Inflammatory response at the spinal cord contributes to central sensitization in the spinal cord, resulting in long lasting thermal hyperalgesia and mechanical allodynia [1 - 3].

Transient Receptor Potential Vanniloid 1 (TRPV1) receptor, a non-selective cation channel has a high $\mathrm{Ca}^{2+}$ permeability and belongs to a family of TRP channels [2, 4 - 8]. Mice lacking TRPV1 receptors exhibit decreased sensitivity to capsaicin and thermal stimulus, implying that TRPV1 is essential for certain modalities of pain [5, 9]. TRPV1 receptors are also expressed in the central terminals of sensory neurons in the spinal cord [4]. Activation of TRPV1 promotes $\mathrm{Ca}^{2+}$ influx into nerve terminals, resulting in the release of neuropeptides like CGRP and SP along with glutamate into the synaptic cleft. These neuropeptides activate their respective receptors (CGRP: calcitonin receptor-like receptor and receptor activity-modifying protein 1; SP: neurokinin 1 receptor), which further activate glia and sensitize second order neurons, thus initiating the process of central sensitization [2, 3, 7, 10, 11]. Blockade of CGRP receptors has been effective in treating animal models of inflammatory or neuropathic pain [12 - 15].

\footnotetext{
* Address correspondence to this author at Department of Pharmacology, Southern Illinois University School of Medicine, Springfield, IL-62702, USA; Tel: 2175452170; Fax: 217545 0145; Email: lpremkumar@siumed.edu
} 
Studies have shown that resiniferatoxin (RTX), an ultrapotent TRPV1 agonist can be an effective long-term analgesic in a number of animal models [6, 16 - 23]. RTX exhibits these effects by its ability to cause depolarization block of the peripheral or central terminals in the short-term and by nerve terminal ablation in the long-term [24, 25]. There is an ongoing clinical trial to treat terminal debilitating pain conditions using intrathecal RTX administration [26; Clinicaltrials.gov: NCT00804154]

In this study, we have used animal models of inflammatory (CFA-induced) and neuropathic (CCI-induced) pain and determined the changes at the spinal cord that include expression and function of TRPV1. Then, we determined the usefulness of intrathecal administration of RTX in alleviating pain associated with these models.

\section{MATERIALS AND METHODS}

\section{Animals}

Experiments were conducted on male Sprague Dawley (250-270 g, n=6-8/group) rats purchased from Harlan laboratories, Indianapolis, IN, USA. The animals were housed under standard laboratory conditions, maintained on a normal light-dark cycle and free access to food and water. The experimental procedures minimized pain, distress and unnecessary discomfort and were approved by the Southern Illinois University School of Medicine Institutional Animal Care and Use in accordance with the Guide for the Care and Use of Laboratory Animals.

\section{CFA and RTX Administration}

Rats were acclimatized to the test conditions 1 hour/day for 5 days before starting the experiments. After having baseline values for thermal and mechanical testing, animals were divided in two groups. Vehicle treated rats ( $\mathrm{n}=6$ ) received $100 \mu \mathrm{l}$ of saline in left hind paw and/or intrathecal (i.t.) saline. Each rat in CFA-treated group ( $\mathrm{n}=15)$ received $100 \mu \mathrm{l}$ of CFA in left hind paw. Animals were assessed for thermal hyperalgesia and mechanical allodynia 3 and 7 days after vehicle/CFA administration. After the experiment on day 7, CFA-treated animals were divided in 3 groups, i.e. CFA-treated, CFA + i.t. RTX $(2 \mu \mathrm{g} / \mathrm{kg} / 20 \mu \mathrm{l})$ and CFA + i.t. RTX $(4 \mu \mathrm{g} / \mathrm{kg} / 20 \mu \mathrm{l})$. Each rat in CFA + i.t. RTX $(2$ $\mu \mathrm{g} / \mathrm{kg} / 20 \mu \mathrm{l}$ ) group received intrathecal (L4/L5 intraspinal space) injection of $2 \mu \mathrm{g} / \mathrm{kg}$ of RTX in $20 \mu \mathrm{l}$ of saline [23]. Each rat in CFA + i.t. RTX $(4 \mu \mathrm{g} / \mathrm{kg} / 20 \mu \mathrm{l})$ group received intrathecal (L4/L5 intraspinal space) injection of $4 \mu \mathrm{g} / \mathrm{kg}$ of RTX in $20 \mu \mathrm{l}$ of saline. Animals received RTX injections under isoflurane anesthesia (2\% oxygen) as described previously [23]. Doses for RTX treatment were selected on the basis of previous studies in our lab. Thermal hyperalgesia and mechanical allodynia was assessed for another 5 weeks. All the experiments involving behavioral studies were performed by the experimenter who was unaware of treatments [22 - 24].

\section{CCI and RTX Administration}

Rats were acclimatized as described above. The rats were anesthetized using intraperitoneal (i.p.) injection of ketamine $(85 \mathrm{mg} / \mathrm{kg})$ and xylazine $(5 \mathrm{mg} / \mathrm{kg})$. The common sciatic nerve of the left hind paw was exposed at the level of the middle of the thigh by blunt dissection through the biceps femoris. Proximal to the sciatic trifurcation, approximately $7 \mathrm{~mm}$ of nerve was freed, and 4 loose ligatures of 4-0 chromic gut were placed around the sciatic nerve. In sham-operated animals were subjected to the same surgical procedure without the ligations. After surgery, all animals were applied analgesic cream containing local anesthetic (Lidocaine) and subcutaneously injected with amoxicillin/clavulinic acid antibiotic. Animals were assessed for thermal hyperalgesia and mechanical allodynia 7 days post-surgery. After the experiment on day 7, CCI animals were divided in 3 groups, i.e. CCI group, CCI group + i.t. saline, CCI + i.t. RTX $(2 \mu \mathrm{g} / \mathrm{kg} / 20 \mu \mathrm{l})$ group [27]. Animals received RTX injections under isoflurane anesthesia (2\% oxygen).

\section{Measurement of Thermal Sensitivity:}

Thermal nociceptive responses were determined using a plantar test instrument (Ugo Basile, Camerio, Italy). The rats were habituated (15 minutes acclimation period) to the apparatus that consisted of three individual Perspex boxes on a glass table. A mobile radiant heat source was located under the table and focused onto the desired paw. Paw Withdrawal Latencies (PWLs) were recorded three times for each hind paw and the average was taken as the baseline value. A timer was automatically activated with the light source, and response latency was defined as the time required for the paw to show an abrupt withdrawal. The apparatus has been calibrated to give a normal PWL of approximately 6-12s. In order to prevent tissue damage a cut-off at 20 s was used. 


\section{Measurement of Mechanical Sensitivity:}

Mechanical nociceptive responses were assessed using a dynamic plantar anesthesiometer instrument using von Frey hairs (Ugo Basile, Camerio, Italy). Each rat was placed in a chamber with a metal mesh floor and was habituated (15 min acclimation period) to the apparatus. A $0.5 \mathrm{~mm}$ diameter von Frey probe was applied to the plantar surface of the rat's hind paw with pressure increasing by $0.05 \mathrm{Newton} / \mathrm{s}$ and the pressure at which a paw withdrawal occurred was recorded and this was taken as Paw Withdrawal Threshold (PWT). For each hind paw, the procedure was repeated 3 times and the average pressure to produce withdrawal was calculated. Successive stimuli were applied to alternating paws at 5 min intervals.

\section{CGRP Release Assay:}

1) Tissue preparation: Five rats from each group were used. Animals were anesthetized using isoflurane (5\%) and oxygen. Spinal cord (hydraulic method) and paw skin was dissected quickly. Lumbar portion of spinal cord ( $0.10 \mathrm{~g}$, range $0.05-0.15 \mathrm{~g})$ and skin flaps $(0.30 \mathrm{~g}$, range $0.25-0.40 \mathrm{~g})$ were collected and were kept for $30 \mathrm{~min}$ in SIF (107.8 $\mathrm{mM}$ $\mathrm{NaCl}, 26.2 \mathrm{mM} \mathrm{NaCO}_{3}, 9.64 \mathrm{mM}$ Na-gluconate, $7.6 \mathrm{mM}$ sucrose, $5.05 \mathrm{mM}$ glucose, $3.48 \mathrm{mM} \mathrm{KCl}, 1.67 \mathrm{mM} \mathrm{NaH}_{2} \mathrm{PO}_{4}$, $1.53 \mathrm{mM} \mathrm{CaCl}_{2}, 0.69 \mathrm{MgSO}_{4}$ ) gassed with $95 \%$ oxygen and $5 \%$ carbon dioxide at $32^{\circ} \mathrm{C}$ for 30 min. These segments were then taken for elution studies.

2) Elution procedures and stimulation: A series of 3 glass tubes were filled with $0.5 \mathrm{ml}$ SIF each and positioned in a temperature controlled shaking bath $\left(32^{\circ} \mathrm{C}\right)$. The release experiment was started by transferring the mounted spinal cord segment/paw skin flap into the first tube. After 5 min incubation, spinal cord segments/ paw skin flap were transferred to the second tube for another $5 \mathrm{~min}$ and then to the third tube for $5 \mathrm{~min}$. After two control samples, stimulation was performed in the third tube with capsaicin (10 iM, Sigma) prepared from the stock (100 mM in ethanol).

For CGRP release assay, $200 \mu$ of elutes were taken from each tube. Spinal cord elutes were further centrifuged at $2000 \mathrm{rpm}$ for 10 minutes. Samples were mixed immediately after the incubation with $50 \mu \mathrm{l}$ of 5 -fold concentrated commercial CGRP EIA buffer containing several protease inhibitors. The CGRP content was determined immediately after the end of the experiment using commercially available enzyme immunoassays (CGRP: SPlbio, France, detection limit=8-10 pg/ml). All EIA plates were determined photometrically using a microplate reader.

\section{Immunohistochemistry:}

Immunofluorescence labeling of TRPV1 receptors and microglial marker (OX-42) and astrocyte marker (GFAP) in spinal dorsal horn was performed on three vehicle- treated, three sham-operated, three CFA-treated and three CCI rats to determine the effect of CFA-treatment and CCI on TRPV1 receptor expression and microglial activation in spinal dorsal horns. Rats were deeply anesthetized with i.p. injection of ketamine $(85 \mathrm{mg} / \mathrm{kg})$ and xylazine $(5 \mathrm{mg} / \mathrm{kg})$ and perfused intracardially with $100 \mathrm{ml}$ ice-cold normal saline followed by $150 \mathrm{ml} 4 \%$ paraformaldehyde in $0.01 \mathrm{M}$ PBS (pH 7.4). The lumbar segment of the spinal cord were quickly removed and post-fixed for $2 \mathrm{hr}$ in the same fixative solution and cryoprotected in $20 \%$ sucrose in $0.01 \mathrm{M} \mathrm{PBS}$ for $24 \mathrm{hr}$ at $4^{\circ} \mathrm{C}$. Following cryoprotection, $15 \mu \mathrm{m}$ sections were cut from lumbar portion of spinal cords using a microtome (Leica CM 1850, North Central Instruments Inc, Plymouth MN, USA).

For TRPV1 receptor, microglial marker (OX-42) and glial fibrillary acidic protein (GFAP) immunostaining, the sections were rinsed in $0.1 \mathrm{M}$ PBS and permeated with $0.1 \%$ triton $\mathrm{X}$ in $0.01 \mathrm{M}$ PBS for 30 minutes. The sections were then blocked in 10\% normal donkey serum in PBS for another 30 minutes. The sections were then incubated overnight with the primary antibody (TRPV1: Guinea anti-TRPV1 N terminal (dilution 1:1000) Neuromics, Minneapolis, MN, USA and microglial activation marker: Mouse anti-CD11b (OX- 42) (dilution 1:100), mouse anti-GFAP antibody (1:100), Novus Biologicals, Littleton, CO, USA) diluted in PBS containing 1\% normal donkey serum, $0.1 \%$ Triton $\mathrm{X}-100$. Subsequently, sections were rinsed in PBS and incubated (1 hour) with the secondary antibody (Rhodamine donkey anti guinea pig IgG (dilution 1:50), Jackson Immuno-research Laboratories, PA, USA) diluted in PBS containing $1 \%$ normal donkey serum, $0.1 \%$ Triton X-100. Sections were washed and fixed. A confocal microscope (Specifications: Intensity- 20\%, Gain-1 (4 for microglia slides), Zoom-1, Offset-0, Scan speed 150-160 seconds, Filter and color tool-normal) was used to view the sections, and areas of interest were photo documented and quantified.

\section{Western Blotting:}

Animals were anesthetized using isoflurane (5\%) and then sacrificed by decapitation. Lumbar portion of spinal cord 
were collected and kept in lysis buffer. Protein levels were determined as described previously [28]. Lysis buffer contains 1X PBS buffer containing 1x Protease Inhibitor (Roche, Indianapolis, IN), EGTA and Phosphatase inhibitors (Phosphatase inhibitor cocktail 1, Sigma and Phosphatase inhibitor cocktail 2, Sigma). Samples were homogenized using sonicator. The tubes were spun at $10,000 \mathrm{rpm}$ for $15 \mathrm{~min}\left(\right.$ at $\left.4^{\circ} \mathrm{C}\right)$ to remove cellular debris. Protein concentration in supernatants was determined by using the Pierce BCA Protein Assay Kit (Thermo Scientific) as per the manufacturers' protocol. Proteins (40 to $80 \mathrm{ig}$ ) were separated by a 12\% SDS-PAGE polyacrylamide gel and transferred to a nitrocellulose membrane. The membrane was blocked with $5 \%$ non-fat milk (Lab Scientific, inc.) dissolved in $0.05 \%$ TBS-T at room temperature for $1 \mathrm{~h}$ (TBS :Tris Buffered Saline was prepared using the formula: $50 \mathrm{mM} \mathrm{Tris-HCl}$, $150 \mathrm{mM} \mathrm{NaOH}, \mathrm{pH}$ 7.5. 0.05\% TBS-T was prepared by adding $50 \mathrm{ml}$ of Triton-X [MP Biomedicals, LLC] to $100 \mathrm{ml}$ of TBS). The membrane was then rinsed with $0.05 \%$ TBS-T and then incubated overnight at $4^{\circ} \mathrm{C}$ in primary antibody. The primary antibodies used were TRPV1 rabbit polyclonal antibody (Santa Cruz) and Tubulin Mouse antibody (1:5000) (Santa Cruz) used as a loading control. The primary antibody solution was removed and the membrane was washed with $0.05 \%$ TBS-T, 3 times for $10 \mathrm{~min}$ each. The membrane was treated using anti-rabbit antibody (IR800) $(1: 10,000)$ or anti-mouse antibody (IR700) (1:5000) for $1 \mathrm{hr}$ at room temperature. The secondary antibody solution was removed and the membranes were washed with $0.05 \%$ TBS-T, 3 times for $10 \mathrm{~min}$ each. All the antibody dilutions were made in SuperBlock Blocking Buffer in TBS (Thermo Scientific). The blots were analyzed using the Li-Cor Odyssey infrared imaging and densitometric analysis was performed using the Li-Cor Odyssey software.

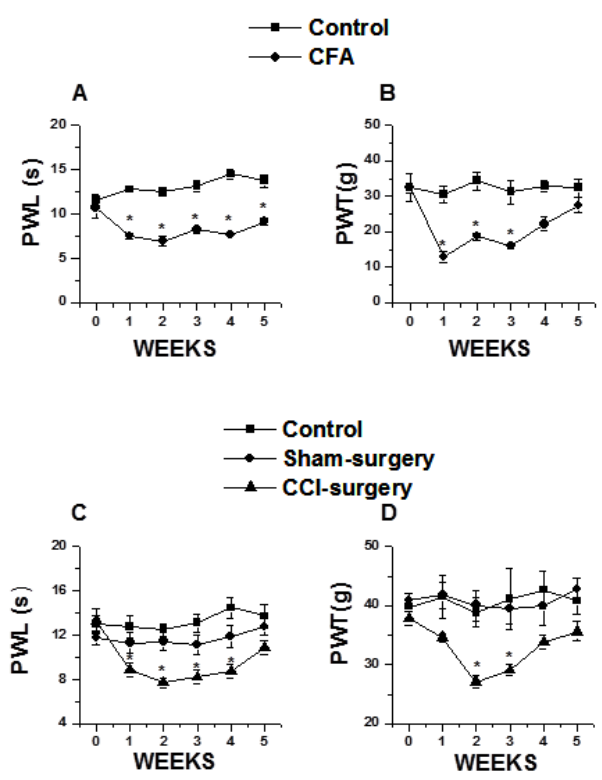

Fig. (1). Effect of intraplantar CFA and CCI on thermal hyperalgesia and mechanical allodynia. A. Intraplantar CFA administration resulted in significant $(p<0.05)$ decrease in PWL at week 1 and lasted for entire duration of study compared to vehicle-treated group. B. Intraplantar CFA administration resulted in significant $(p<0.05)$ decrease in PWT at week 1 after treatment compared to vehicletreated group thus inducing thermal hyperalgesia and mechanical allodynia. C. CCI resulted in significant $(p<0.05)$ decrease in PWL at week 1 and returned to baseline by week 5 of study compared to vehicle-treated group. D. CCI resulted in significant $(p<0.05)$ decrease in PWT at week 2 and returned to baseline by week 4 of study compared to vehicle-treated group. Asterisks $\left(^{*}\right)$ represent $p$ $<0.05$ as compared to vehicle-treated or sham-surgery animals.

\section{Statistical Analyses:}

Statistical analysis was performed using SPSS software. Data are presented as mean \pm SEM. Student T test was used to compare two groups. Descriptive one way ANOVA followed by post hoc Tukey's HSD was used to compare more than 2 groups. A $p$ value of $<0.05$ was considered as statistically significant.

\section{RESULTS}

Effect of intraplantar administration of CFA and CCI of the sciatic nerve on thermal hyperalgesia and mechanical allodynia

Intraplantar administration of CFA and CCI by sciatic nerve ligation were used as models of peripheral nerve 
injury-induced pain. First, we characterized the pain thresholds for each of these two pain models. Pain thresholds were measured by the two commonly used techniques: 1) Thermal pain testing (Hargreaves' test) and 2) Mechanical pain testing (von Frey test). Animals were acclimatized in plexi-glass chambers for a week before testing for thermal and mechanical pain sensitivities. Animals were randomly divided into four groups: 1) vehicle-treated; injected with intraplantar saline, 2) CFA-treated; injected with intraplantar $100 \mu \mathrm{lCFA}, 3$ ) sham-operated and 4) CCI-induced by sciatic nerve ligation.
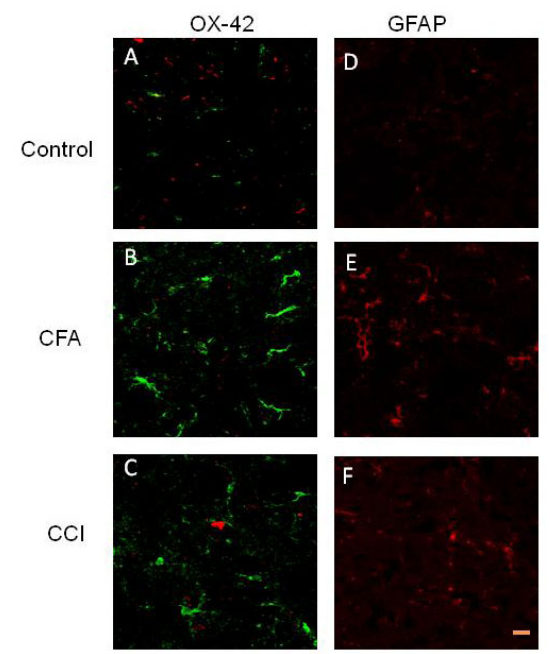

Fig. (2). Altered OX-42 (Microglial activation) and GFAP (astroglial activation) staining in spinal cord (L4-L5) dorsal horn of CFAtreated and CCI-induced rats. A,B,C. Representative images of OX-42 staining from a vehicle-treated, CFA-treated and CCI rats. D,E,F. Representative images of GFAP staining from a vehicle-treated, CFA- treated and CCI rats. [Scale bar is $50 \mu \mathrm{m}$ ].

Intraplantar administration of CFA significantly decreased PWL (vehicle: week 0, 11.58 $\pm 0.76 \mathrm{~s}$, week 1, $12.75 \pm 0.23 \mathrm{~s}, \mathrm{n}=6$; CFA: week 0, 10.69 $\pm 1.1 \mathrm{~s}$, week 1, 7.48 $\pm 0.36 \mathrm{~s}, \mathrm{n}=12, p<0.05$ ) (Fig. 1A). Thermal hyperalgesia

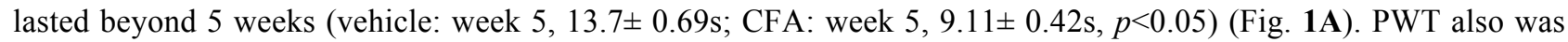
significantly decreased following CFA administration (vehicle: week 0, 32.29 $\pm 1.25 \mathrm{~g}$, week 1, 30.61 $\pm 2.34 \mathrm{~g}$; $\mathrm{n}=6$; CFA: week 0, 32.42 $\pm 3.98 \mathrm{~g}$, week 1, 12.92 $\pm 1.54 \mathrm{~g}, \mathrm{n}=12, p<0.05$ ) (Fig. 1B). Mechanical allodynia lasted for 4 weeks and there was no difference in PWT between vehicle-treated and CFA-treated animals by the end of week 5 (vehicle: week 5, 32.42 $\pm 2.54 \mathrm{~g}$; and CFA: week 5, 27.41 $\pm 2.21 \mathrm{~g}$ ) (Fig. 1B).

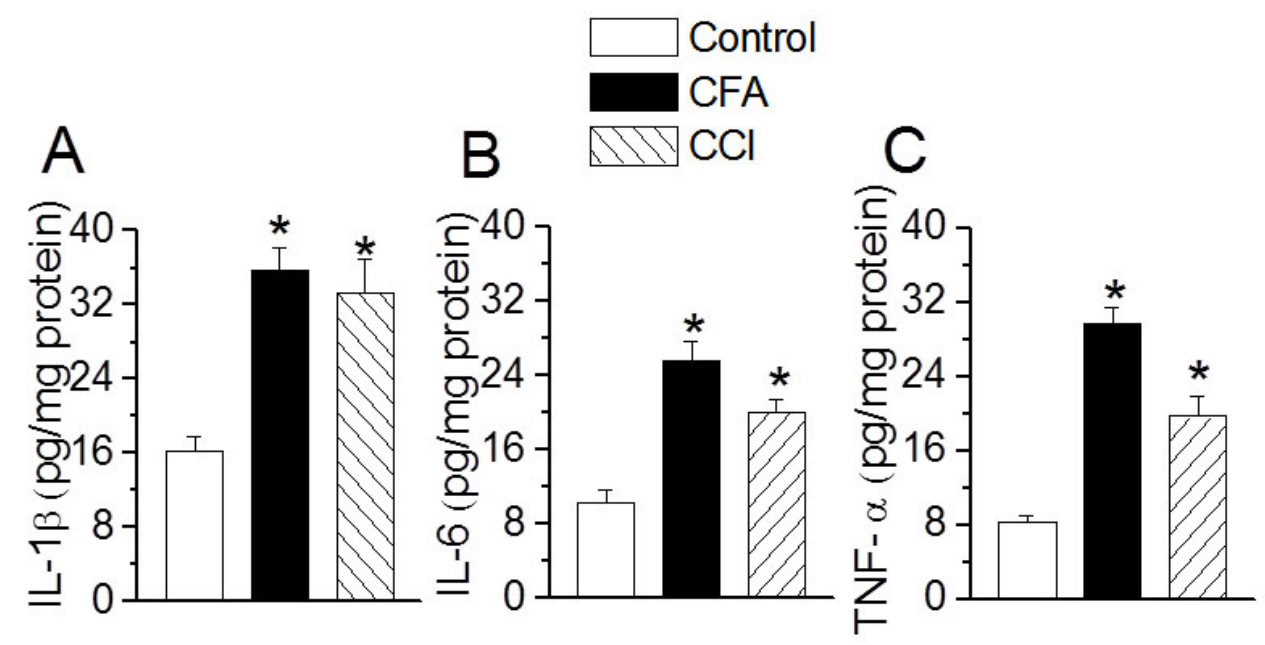

Fig. (3). Effect of intraplantar $\mathrm{CFA}$ and $\mathrm{CCl}$ on spinal pro-inflammatory cytokine levels. CFA-treatment and CCI resulted in a significant increase in interleukin-1beta (IL-1 $\beta$ ) (A) Interleukin-6 (IL-6) (B) Tumor necrosis factor- $\alpha$ (TNF- $\alpha$ ) (C) In lumbar spinal cord tissue homogenates as assessed by ELISA. Statistically significant data are denoted by an asterisk $\left(^{*}\right), p<0.05$ as compared to control or vehicle-treted rats. 
Chronic constriction nerve injury significantly decreased PWL (sham-operated: week $0,11.78 \pm 0.65 \mathrm{~s}$, week 1 , $11.32 \pm 0.96 \mathrm{~s}$; CCI-induced: week 0, 13.32 $\pm 1.14 \mathrm{~s}$, week $1,8.85 \pm 0.65 \mathrm{~s}, p<0.05$ ) (Fig. 1C). In these experimental conditions, the thermal hyperalgesia lasted for 4 weeks following CCI and the values were not significantly different by week 5 (sham-operated: week 5, $12.78 \pm 1.02 \mathrm{~s}$; and CCI: week 5, 10.88 $\pm 0.66 \mathrm{~s}$; Fig. 1C). The PWT also significantly

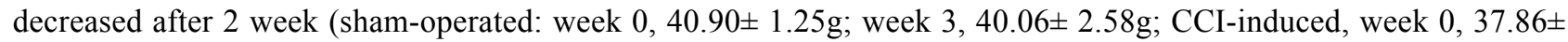
2.46g; week 3, 27.13 $\pm 1.58 \mathrm{~g}, p<0.05$ ) (Fig. 1D). This decrease in PWT following CCI lasted for 3 weeks and was not significantly different from sham-operated by week 5 (sham-operated: week 5, 42.77 $\pm 1.89 \mathrm{~s}$; CCI-induced: week 5 , $35.63 \pm 1.65 \mathrm{~s}$ ) (Fig. 1D). These data suggest that there are differences in the extent of nerve injury, which can be correlated with the degree of thermal hyperalgesia and mechanical allodynia caused by these two different models of peripheral nerve injury. Intraplantar CFA administration has a long lasting effect on thermal hyperalgesia as compared to the CCI.

\section{Microglial and Astroglial Activation Following Intraplantar CFA Administration and CCI}

Microglial and astroglial activation plays a key role in maintenance of thermal hyperalgesia and mechanical allodynia. Here we determined the glial activation by immuno histochemical staining of spinal cord sections. We used OX-42 staining for demonstrating microglial activation, while GFAP staining was used to visualize activated astrocytes. Following either CFA-treatment or CCI, there was a qualitative increase in OX-42 staining (Figs. 2A, B, C) as well as GFAP staining (Figs. 2D, E, F) in laminae I and II. These data suggest that in both the models of peripheral injury caused activation of microglia and astroglia in the spinal cord.

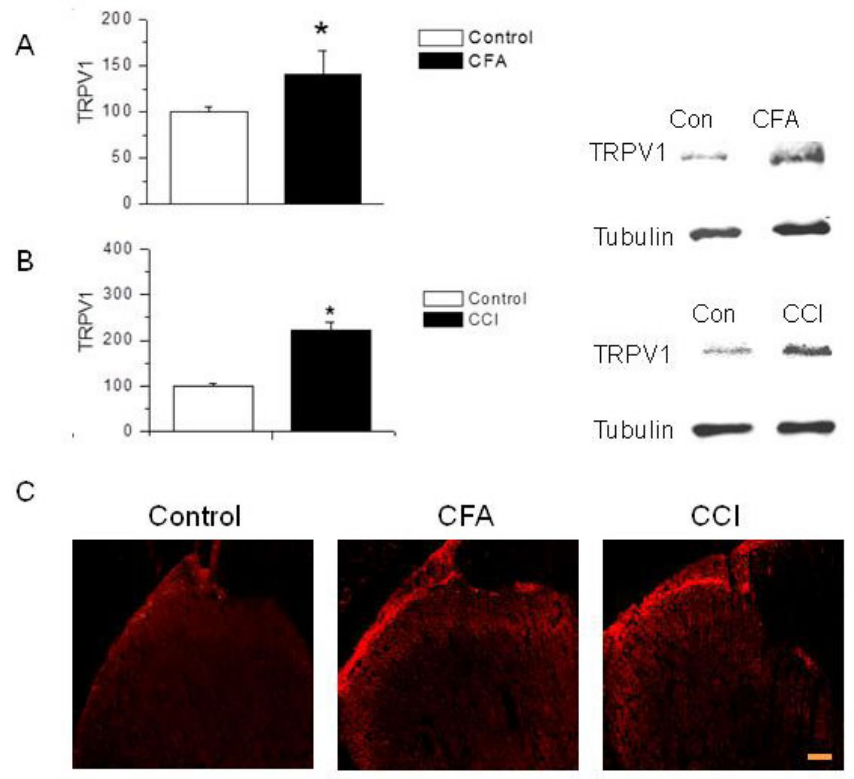

Fig. (4). Expression of TRP channels in CFA-treated and CCI-induced animals. A. Intraplantar CFA administration resulted in significant $(p<0.05)$ increase in expression of TRPV1 in spinal cord as compared to vehicle treated group. B. CCI resulted in significant $(p<0.05)$ increase in expression of TRPV1 in spinal cord tissue as compared to vehicle-treated group. Asterisks $(*)$ represent $p<0.05$ as compared to vehicle-treated animals. C. Immunohistochemical staining shows enhanced expression of TRPV1 in spinal dorsal horn in CFA-treated and CCI-induced animals.

\section{Effect of Intraplantar CFA and CCI on Spinal Pro-inflammatory Cytokines}

Recent literature has provided substantial evidence for the role of pro-inflammatory mediators in the initiation and maintenance of thermal hyperalgesia and mechanical allodynia (1). CFA-treatment and CCI significantly increased the levels of pro-inflammatory cytokines (IL-1 $\beta$, IL-6, TNF- $\alpha$ ) in the spinal cord homogenates (IL-1 $\beta$ : vehicle, $16.32 \pm$ 1.55; CFA, 35.68 \pm 2.56 ; CCI, 33.26 $\pm 365 \mathrm{pg} / \mathrm{mg}$ protein, $\mathrm{n}=5, p<0.05$, Fig. (3A) ; IL-6: vehicle, 10.25 \pm 0.65 ; CFA, $25.69 \pm 1.86$; CCI, $19.69 \pm 2.25 \mathrm{pg} / \mathrm{mg}$ protein, $\mathrm{n}=5, p<0.05$, Fig. (3B) ; TNF- $\alpha$ : vehicle, $8.32 \pm 0.65$; CFA, $29.65 \pm$ 1.86 ; CCI, $19.69 \pm 2.25 \mathrm{pg} / \mathrm{mg}$ protein, $\mathrm{n}=5, p<0.05$, Fig. (3C). These data suggest that the increases in proinflammatory mediators in the spinal cord are associated with peripheral nerve activity in CFA- and CCI-induced pain. 


\section{TRPV1 Expression Following Intraplantar Administration of CFA and CCI}

Next, we wanted to compare the changes in TRPV1 expression at the height (week 2) of thermal hyperalgesia and mechanical allodynia. We accomplished this goal by measuring changes in the expression of nociceptive ion channels TRPV1 at the L4-L6 segments of spinal cord. The Western blot analysis of spinal cord samples at week 2 showed that both, CFA-treated and CCI-induced animals revealed a significant increase in expression of TRPV1 (CFA-treated, 1.5 fold and CCI-induced, 2 fold, respectively; $\mathrm{n}=3 ; p<0.05$, Figs. (4A and 4B). We also performed immuno-histochemical analysis to visualize TRPV1 expression in spinal cord. Both CFA-treatment and CCI resulted in an increase in intensity of TRPV1 in lamina I of dorsal horn of spinal cord compared to vehicle-treated group (Fig. 4C). These results suggest a significant increase in the expression of TRPV1 in the central sensory nerve terminals that form synapses with the second order neurons. TRPV1 has been shown to be expressed only in sensory nerve terminals in the spinal cord [24, $29,30]$. However, recently it has been shown that TRPV1 is also expressed in inhibitory interneurons in the spinal cord [31].

\section{Intraplantar CFA Administration and CCI on TRPV1-Mediated CGRP Release}

As indicated earlier, both peripheral and central terminals of the sensory neurons express TRPV1. Following the observation that intraplantar CFA administration and CCI increased the expression of TRPV1 in spinal dorsal horn, we hypothesized that intraplantar CFA administration and CCI affect TRPV1-mediated functions such as neuropeptide release in central terminals of DRG neurons [22 - 24]. TRPV1-mediated CGRP release is a reliable assay to determine the expression and function of TRPV1. The neuropeptide release was normalized to the weight of the spinal cord tissue. The basal CGRP levels were significantly increased in both CFA-treated and CCI-induced groups as compared to vehicle-treated group at week 2 (vehicle, $12.74 \pm 0.9$; CFA, $18.5 \pm 1.71$; CCI, $21.56 \pm 0.99 \mathrm{ng} / \mathrm{g}$ tissue $/ 5 \mathrm{~min} ; p<0.05$ ) (Fig. 5A). To specifically compare the role of TRPV1, we examined capsaicin-evoked CGRP release. Incubation of spinal cord tissue with capsaicin $(1 \mu \mathrm{m})$ for 5 min significantly increased CGRP release in vehicle-treated and CFAtreated animals. The magnitude of $1 \mu \mathrm{M}$ capsaicin-stimulated CGRP release was significantly greater in CFA-treated and CCI-induced rats at week 2 (vehicle, $42.56 \pm 4.22$; CFA, $58.55 \pm 5.5$; CCI, $71.45 \pm 9.6 \mathrm{ng} / \mathrm{g}$ tissue $/ 5 \mathrm{~min} ; p<0.05$ ) (Fig. 5B). These data demonstrate that TRPV1 expression and functions are enhanced in the spinal cord following peripheral administation of CFA or following CCI of sciatic nerve.

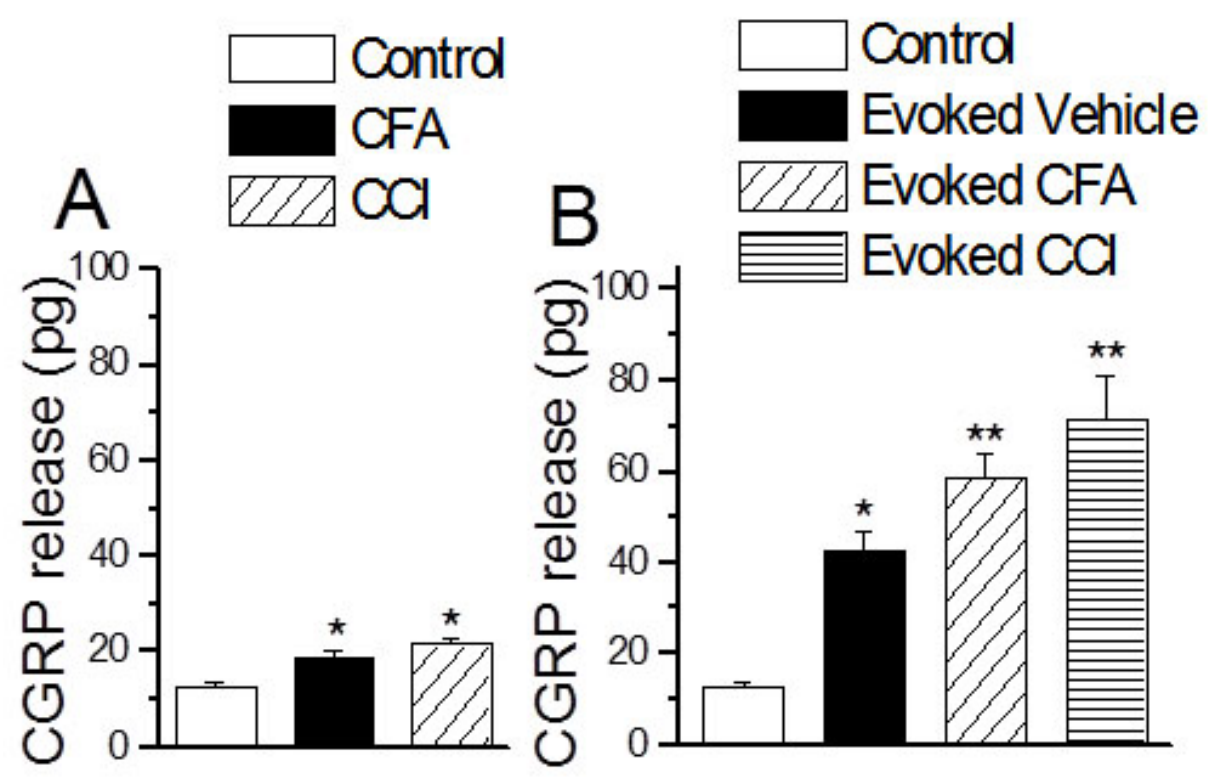

Fig. (5). Change in basal and capsaicin-evoked CGRP release after intraplantar CFA administration and CCI. A. Both intraplantar CFA administration and CCI resulted in significant $(p<0.05)$ increases in the basal-CGRP release as compared to vehicle treated group. B. Both intraplantar CFA administration and CCI resulted in significant $(p<0.05)$ increase in the capsaicin evoked-CGRP release as compared to capsaicin evoked-CGRP release in vehicle treated group. Capsaicin evoked-CGRP release in vehicle-treated group was significantly higher than basal CGRP release in vehicle treated group. Statistically significant results are denoted by asterisks $\left(^{*}\right)$ and $(* *)$ represent $p<0.05$ or $p<0.01$ as compared to basal-CGRP and capsaicin evoked-CGRP release in vehicle-treated rats, respectively. 


\section{Effect of Intrathecal Administration of RTX on CFA- and CCI-Induced Thermal Hyperalgesia and Mechanical Allodynia}

In this section, we determined whether intrathecal administration of RTX can alleviate thermal hyperalgesia and mechanical allodynia in models of peripheral injury that lead to chronic pain conditions. One week after intraplantar administration of CFA, animals were injected with intrathecal RTX ( 2 and $4 \mu \mathrm{g} / \mathrm{kg} / 20 \mu \mathrm{l})$. We have previously shown that intrathecal injection of vehicle did not cause changes in thermal and mechanical sensitivities [23, 24]. Both 2 and 4 $\mu \mathrm{g} / \mathrm{kg}$ dose of RTX significantly attenuated the increase in PWL over the period of 5 weeks (week 1 after RTX injection, vehicle, $13.74 \pm 1.22 \mathrm{~s}$; CFA, 9.11 0.74.s, CFA + RTX $(2 \mu \mathrm{g} / \mathrm{kg} / 20 \mu 1), 14.78 \pm 1.05 . \mathrm{s}$; CFA + RTX (4 $\mu \mathrm{g} / \mathrm{kg} / 20 \mu \mathrm{l}), 15.91 \pm 0.96 \mathrm{~s} ; p<0.05$, Fig. (6A) but didn't attenuate PWT week 1 after RTX injection, vehicle, $34.33 \pm$ 2.42g; CFA, $18.72 \pm 1.58 \mathrm{~g}$, CFA + RTX $(2 \mu \mathrm{g} / \mathrm{kg} / 20 \mu \mathrm{l}), 21.83 \pm 2.62 \mathrm{~g} ;$ CFA + RTX (4 $\mu \mathrm{g} / \mathrm{kg} / 20 \mu \mathrm{l}), 19.17 \pm 1.06 \mathrm{~g}$; $p<0.05$, Fig. (6B). There was no significant difference in the efficacy of the two doses, both exhibiting similar profile. Based on these experiments, we suggest that, $2 \mu \mathrm{g} / \mathrm{kg}$ dose of RTX is sufficient to ablate TRPV1 terminals in lumbar region of spinal cord and alleviate thermal hyperalgesia.

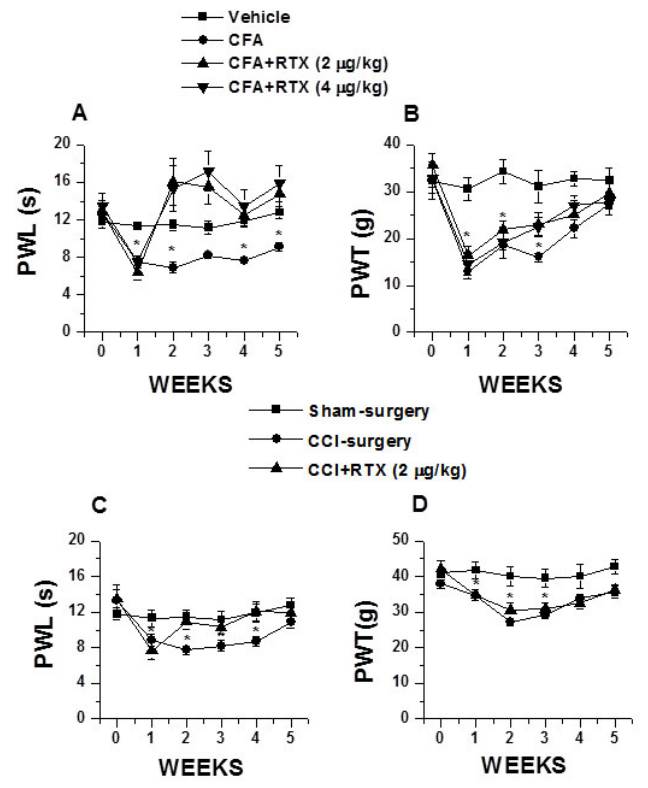

Fig. (6). Effect of intrathecal administration of RTX on intraplantar CFA and chronic constriction nerve injury induced thermal hyperalgesia and mechanical allodynia. A,C. RTX attenuated thermal hyperalgesia in both CFA-treated and CCI rats. B,D. RTX administration did not have any effect on mechanical allodynia in both CFA-treated and CCI-induced rats. Statistically significant results are denoted by an asterisk $(*), p<0.05$.

Similarly, following one week after surgery to induce CCI, one group of animals was injected with intrathecal RTX $(2 \mu \mathrm{g} / \mathrm{kg} / 20 \mu \mathrm{l})$. Intrathecal administration of RTX significantly attenuated the increase in PWL (week 1 after RTX injection: Sham surgery, $11.78 \pm 0.93 \mathrm{~s} ; \mathrm{CCI}, 8.88 \pm 1.37 \mathrm{~s}, \mathrm{CCI}+\mathrm{RTX}(2 \mu \mathrm{g} / \mathrm{kg} / 20 \mu \mathrm{l}), 11.90 \pm 0.85 \mathrm{~s} ; p<0.05$, Fig. (6C) but did not change PWT (week 1 after RTX injection: Sham surgery, 40.06 $\pm 2.35 \mathrm{~g}$; CCI, 27.13 $\pm 1.74 \mathrm{~g}, \mathrm{CCI}+\mathrm{RTX}(2$ $\mu \mathrm{g} / \mathrm{kg} / 20 \mu \mathrm{l}), 30.47 \pm 2.05 \mathrm{~g} ; p<0.05$, Fig. (6D). As there is convincing literature suggesting the involvement of TRPV1 in thermal hyperalgesia but not in mechanical allodynia, these findings attest to a selective effect of RTX against thermal hyperalgesia.

\section{Effect of Intrathecal Administration of RTX on TRPVI Mediated CGRP Release}

RTX administration can selectively ablate TRPV1 expressing nerve terminals in spinal cord [24]. In order to confirm that intrathecal RTX administration ablated TRPV1 receptor expressing nerve terminals in the spinal cord, we determined the functionality of TRPV1 receptors using CGRP release assay. RTX treatment $(2 \mu \mathrm{g} / \mathrm{kg} / 20 \mu \mathrm{l})$ significantly inhibited the increase in capsaicin-stimulated CGRP release in spinal cord samples following CFAtreatment and CCI (vehicle, 42.56 \pm 4.22; CFA, 9.44 \pm 0.87; CCI, 18.26 $\pm 1.52 \mathrm{pg} / \mathrm{g}$ tissue $/ 5 \mathrm{~min}$ Fig. (7A). These results suggest that capsaicin-stimulated CGRP release in spinal cord is a TRPV1-dependent process. Intrathecal administration of RTX ablates TRPV1 expressing nerve terminals in spinal dorsal horn; thereby preventing TRPV1- 
mediated CGRP release.

TRPV1-mediated peripheral CGRP release plays an important role in maintaining vasodilation and regulating micro vascular circulation. In order to confirm that intrathecal RTX can selectively ablate TRPV1 expressing central terminals in the spinal cord, we determined CGRP release from paw skin samples. Treatment with intrathecal RTX $(2 \mu \mathrm{g} / \mathrm{kg} / 20 \mu \mathrm{l})$ did not significantly change capsaicin-stimulated CGRP release in both CFA-treated (48.81 $\pm 9.25 v s$. $52.72 \pm 3.86 \mathrm{pg} / \mathrm{g}$ tissue $/ 5 \mathrm{~min})$ and CCI-induced $(84.44 \pm 11.61 \mathrm{vs} .77 .81 \pm 5.68 \mathrm{pg} / \mathrm{g}$ tissue $/ 5 \mathrm{~min}$; Fig. (7B) animals. These observations suggest that intrathecal injection of RTX does not affect the TRPV1-mediated CGRP release from paw skin, thus preserving peripheral nerve function of CGRP release.

\section{DISCUSSION}

Central sensitization has been extensively studied [3] and has been shown to involve glutamatergic, gabaeric and opioidergic systems along with microglial activation, synthesis and release of neuropeptides (CGRP/SP), cytokines and chemokines [1 - 3, 32 - 35]. Inhibition of glial activation leads to attenuation of neuropathic pain in several models [36, 37]. Activation of TRP channels expressed in the nerve terminals can lead to influx of $\mathrm{Ca}^{2+}$ and cause glutamate and CGRP release, which can subsequently activate their respective receptors in glia and mediate an inflammatory response $[7,8,24,33,38-40]$. Although there is restricted expression of TRPV1 in the central nervous system [24, 29, 30], studies have also shown that TRPV1 is expressed in glial cells [7, 38]. Several pro-inflammatory mediators are released from activated microglia. We have observed that there is a significant increase in the levels of pro-inflammatory mediators IL-1 $\beta$, IL-6 and TNF- $\alpha$. These mediators can interact with TRPV1 expressing cells and alter TRPV1 expression and function [41, 42]. Peripheral inflammation (intraplantar CFA-treatment) and peripheral nerve injury (CCI) have been shown to increase the levels of phosphorylated p38 and ERK in spinal cord tissue [43 - 49]. Activation of MAPKs in glial cells is necessary for the development and maintenance of neuropathic pain [50 - 52].

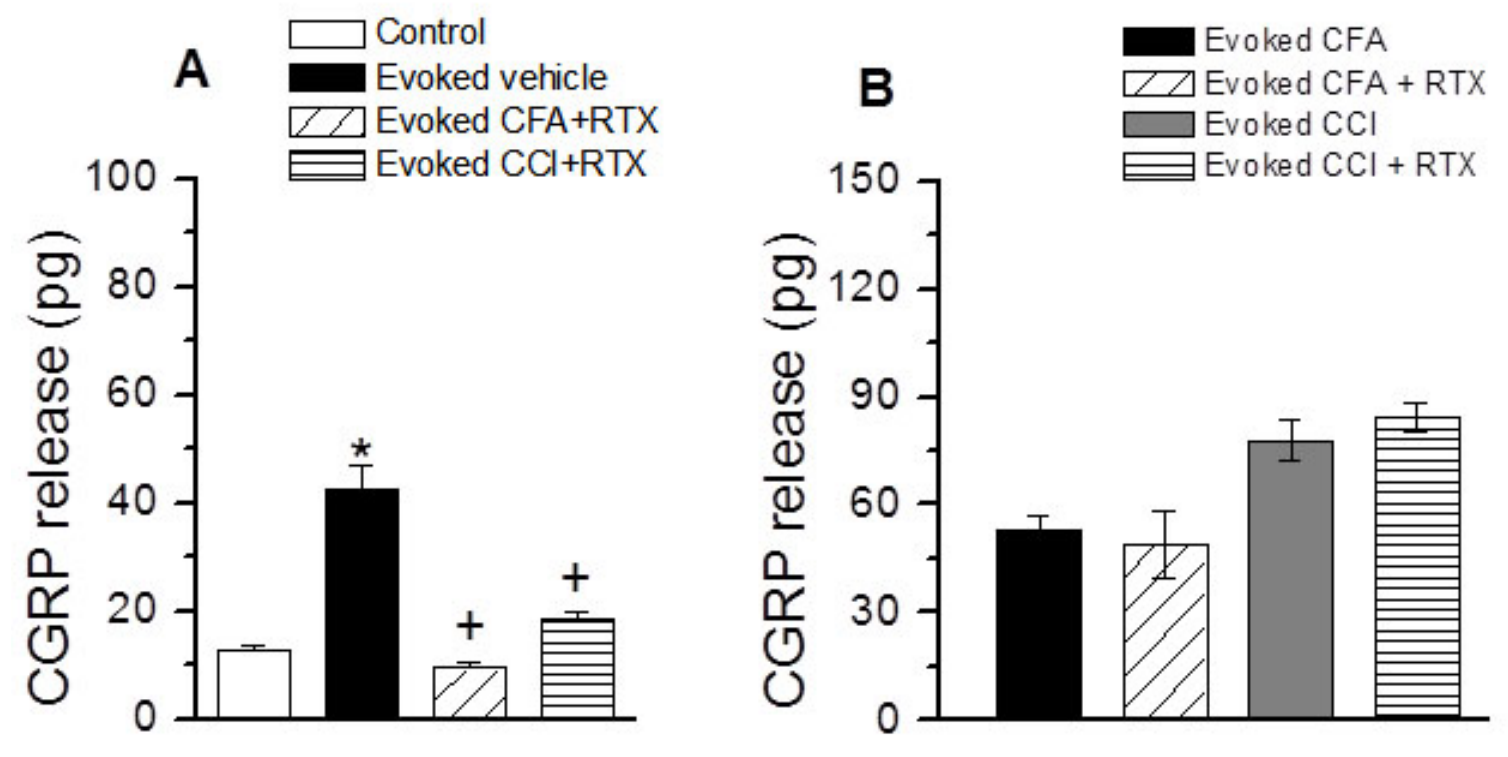

Fig. (7). Effect of intrathecal administration of RTX on TRPV1-mediated CGRP release. A. Intrathecal RTX treatment resulted in significant decrease in capsaicin evoked-CGRP release in CFA-treated and CCI-induced rats in spinal cord samples. B. Intrathecal RTX treatment did not significantly change the capsaicin evoked-CGRP release in CFA-treated and CCI-induced paw skin samples. Statistically significant results are denoted by an asterisk (*, increase) and a plus ( + , decrease), $p<0.05$.

The physiological role of TRPV1 expressed in the central terminals of sensory neurons is not fully understood. Activation of TRPV1 in the central terminals modulates synaptic transmission [24, 33, 53 - 55]. In order to attribute a role for TRPV1, we determined the expression levels of TRPV1 by Western blot and immunohistochemistry techniques. The Western blot analysis revealed that in both models, there was a significant increase in TRPV1 expression at the dorsal horn. This was further confirmed by immuno-histochemical analysis, which showed an increase in intensity of TRPV1 staining in spinal dorsal horn. In order to confirm that increased TRPV1 expression results in functional changes, we determined TRPV1-mediated CGRP release. CGRP is stored in vesicles of both peripheral and 
central terminals and is released when extracellular $\mathrm{Ca}^{2+}$ enters the terminals. Enhanced CGRP release occurs from central terminals during peripheral nerve injury and peripheral inflammation [56 - 58]. There are studies showing that CGRP is involved in peripheral, spinal, and supra-spinal pain mechanisms [57, 59, 60]. The released CGRP binds to its receptor on second order neurons and glia, leading to change in receptor expression and function. Activated glia release inflammatory mediators, which act on their respective receptors in the neurons and alter neuronal activity, thus contributing to central sensitization. Our studies show that in both models, intraplantar CFA-treatment and CCI not only increased basal CGRP release, but also increased TRPV1-mediated CGRP release. These findings further support the hypothesis that peripheral nerve activity leads to increased TRPV1 expression and function in the spinal cord.

The results obtained from this study show that intrathecal (L4-L5) administration of RTX resulted in reversal of PWL induced by intraplantar administation of CFA and CCI of the sciatic nerve; while intrathecal RTX treatment did not show any effect on mechanical allodynia (PWT). This result is consistent with the fact that TRPV1 is major contributor of inflammatory thermal hyperalgesia. Previous studies from our lab and other labs have shown that RTX selectively ablated central terminals of TRPV1 expressing neurons resulting in reversal of thermal hyperalgesia [16, 18 - 20, 22 - 24]. We propose that selective ablation/blockade of TRPV1-expressing central terminals is sufficient to cause long lasting pain relief sparing the DRG cell bodies and peripheral terminals intact. We have also reported that intrathecal administration of RTX (targeting central terminals) selectively abolishes inflammatory thermal hypersensitivity without affecting acute thermal pain sensitivity, whereas intraperitoneal administration of RTX (targeting the whole TRPV1 expressing neuron) affects both acute and inflammatory thermal hyperalgesia [23]. Analgesic effects of localized application of RTX can be explained by its ability to cause depolarization block of the peripheral or central nerve terminals in the short-term and nerve terminal ablation in the long term [24, 25, 33]. These observations further validate the claim that TRPV1 is involved in inflammatory thermal but not mechanical hypersensitivity [5, 21, 30,61], although some studies have shown that selective agonists and antagonists of TRPV1 affected mechanical sensitivity [62 - 64]. It is possible that TRPV1 expressed in the inhibitory interneurons [31], when blocked reduces inhibition and exaggerates transmission of mechanical sensitivity. While using agonists, it is important to consider the concentrations of agonists used, which may either result in partial or total ablation of TRPV1 expressing nerve terminals impacting the mechanical sensitivity.

Here, we interpret that attenuation of thermal hyperalgesia and CGRP release from central terminals by RTX as ablation of TRPV1 expressing nerve terminals as a result of sustained activation resulting in excessive $\mathrm{Ca}^{2+}$ influx $[6,17,24]$. However, we cannot rule out the possibility that sustained activation of TRPV1 leading to receptor internalization. If only TRPV1 internalization occurs after intrathecal RTX administration and the nerve terminal integrity is maintained, the propagation of action potential should not be impacted. However, we are able to observe a selective alleviation of inflammatory thermal hypersensitivity, which argues against receptor internalization. We also measured CGRP release from peripheral terminals to determine the effect of intrathecal administration of RTX on peripheral TRPV1 function, which show that TRPV1-dependent CGRP release was unaffected following CFAtreatment and CCI. Peripheral TRPV1 function is necessary to maintain micro vascular circulation [2, 65]. TRPV1mediated CGRP release has been shown to be important for maintaining cardiovascular function [66]. Intrathecal administration of RTX, only affected the central terminals, sparing the rest of the neuron, which included the cell bodies $[22,24]$. However, following intraperitoneal administation of RTX, CGRP release from the peripheral and central terminals was abolished as a result of whole TRPV1- expressing neuronal loss [23].

\section{CONCLUSION}

Peripheral neuronal activity induced by administation of CFA or CCI causes neuropeptide (CGRP) release. CGRP acting on its receptors triggers glial activation, which alters the extracellular milieu at the dorsal horn by synthesizing and releasing inflammatory mediators. Inflammatory mediators acting on their respective receptors trigger downstream signaling cascades leading to transcriptional, translational and posttranslational changes of receptors, including TRP channels. Targeting central TRPV1 expressed at the dorsal horn by intrathecal administration of RTX, selectively alleviates inflammatory thermal hypersensitivity in a long-term basis, which can be a useful strategy to treat certain modalities of chronic pain.

\section{LIST OF ABBREVIATIONS}

CCI: Chronic Constriction Injury

CFA: Complete Freund's adjuvant 
CGRP: Calcitonin Gene Related peptide

DRG: Dorsal Root Ganglion

ERK: Extracellular Signal-regulated Protein Kinase

IL-6: Interleukin6

IL-1 $\beta$ : Interleukin $1 \beta$

MAPK: Mitogen Activated Protein Kinase

PWL: Paw Withdrawal Latency

PWT: Paw Withdrawal Threshold

RTX: Resiniferatoxin

TNF- $\alpha$ : Tumor Necrosis Factor $\alpha$

TRPV1: Transient Receptor Potential Vanilloid 1

TRPA1: Transient Receptor Potential Ankyrin 1

\section{AUTHORS' CONTRIBUTIONS}

MA performed the Western blot, ELISA, designed the study and drafted the manuscript. MB performed the drug administration, surgery, ELISA, immunofluorescence and designed the study. CB performed the behavioral tests. LP designed the study and drafted the manuscript. All authors read and approved the final manuscript.

\section{CONFLICT OF INTEREST}

The authors confirm that this article content has no conflict of interest.

\section{ACKNOWLEDGEMENTS}

Supported by grants from National Institutes of Health (DA028017) and EAM award from SIUSOM.

\section{REFERENCES}

[1] Watkins LR, Milligan ED, Maier SF. Glial proinflammatory cytokines mediate exaggerated pain states: implications for clinical pain. Adv Exp Med Biol 2003; 521: 1-21.

[PMID: 12617561]

[2] Scholz J, Woolf CJ. The neuropathic pain triad: neurons, immune cells and glia. Nat Neurosci 2007; 10(11): 1361-8. [http://dx.doi.org/10.1038/nn1992] [PMID: 17965656]

[3] Woolf CJ. Central sensitization: implications for the diagnosis and treatment of pain. Pain 2011; 152(3)(Suppl.): S2-15. [http://dx.doi.org/10.1016/j.pain.2010.09.030] [PMID: 20961685]

[4] Caterina MJ, Schumacher MA, Tominaga M, Rosen TA, Levine JD, Julius D. The capsaicin receptor: a heat-activated ion channel in the pain pathway. Nature 1997; 389(6653): 816-24. [http://dx.doi.org/10.1038/39807] [PMID: 9349813]

[5] Caterina MJ, Leffler A, Malmberg AB, et al. Impaired nociception and pain sensation in mice lacking the capsaicin receptor. Science 2000; 288(5464): 306-13.

[http://dx.doi.org/10.1126/science.288.5464.306] [PMID: 10764638]

[6] Szallasi A, Cortright DN, Blum CA, Eid SR. The vanilloid receptor TRPV1: 10 years from channel cloning to antagonist proof-of-concept. Nat Rev Drug Discov 2007; 6(5): 357-72. [http://dx.doi.org/10.1038/nrd2280] [PMID: 17464295]

[7] Sappington RM, Calkins DJ. Contribution of TRPV1 to microglia-derived IL-6 and NFkappaB translocation with elevated hydrostatic pressure. Invest Ophthalmol Vis Sci 2008; 49(7): 3004-17. [http://dx.doi.org/10.1167/iovs.07-1355] [PMID: 18362111]

[8] Chen Y, Willcockson HH, Valtschanoff JG. Influence of the vanilloid receptor TRPV1 on the activation of spinal cord glia in mouse models of pain. Exp Neurol 2009; 220(2): 383-90.

[http://dx.doi.org/10.1016/j.expneurol.2009.09.030] [PMID: 19815011]

[9] Davis JB, Gray J, Gunthorpe MJ, et al. Vanilloid receptor-1 is essential for inflammatory thermal hyperalgesia. Nature 2000; 405(6783): 183-7. [http://dx.doi.org/10.1038/35012076] [PMID: 10821274]

[10] Wimalawansa SJ. Calcitonin gene-related peptide and its receptors: molecular genetics, physiology, pathophysiology, and therapeutic potentials. Endocr Rev 1996; 17(5): 533-85. [http://dx.doi.org/10.1210/edrv-17-5-533] [PMID: 8897024]

[11] van Rossum D, Hanisch UK, Quirion R. Neuroanatomical localization, pharmacological characterization and functions of CGRP, related peptides and their receptors. Neurosci Biobehav Rev 1997; 21(5): 649-78. 
[http://dx.doi.org/10.1016/S0149-7634(96)00023-1] [PMID: 9353797]

[12] Yu LC, Hansson P, Brodda-Jansen G, Theodorsson E, Lundeberg T. Intrathecal CGRP8-37-induced bilateral increase in hindpaw withdrawal latency in rats with unilateral inflammation. Br J Pharmacol 1996; 117(1): 43-50. [http://dx.doi.org/10.1111/j.1476-5381.1996.tb15152.x] [PMID: 8825341]

[13] Yu LC, Hansson P, Lundeberg S, Lundeberg T. Effects of calcitonin gene-related peptide-(8-37) on withdrawal responses in rats with inflammation. Eur J Pharmacol 1998; 347(2-3): 275-82. [http://dx.doi.org/10.1016/S0014-2999(98)00102-2] [PMID: 9653894]

[14] Sun RQ, Lawand NB, Willis WD. The role of calcitonin gene-related peptide (CGRP) in the generation and maintenance of mechanical allodynia and hyperalgesia in rats after intradermal injection of capsaicin. Pain 2003; 104(1-2): 201-8. [http://dx.doi.org/10.1016/S0304-3959(03)00008-3] [PMID: 12855330]

[15] Bennett AD, Chastain KM, Hulsebosch CE. Alleviation of mechanical and thermal allodynia by CGRP(8-37) in a rodent model of chronic central pain. Pain 2000; 86(1-2): 163-75.

[http://dx.doi.org/10.1016/S0304-3959(00)00242-6] [PMID: 10779673]

[16] Szabo T, Olah Z, Iadarola MJ, Blumberg PM. Epidural resiniferatoxin induced prolonged regional analgesia to pain. Brain Res 1999; 840(1-2): 92-8. [http://dx.doi.org/10.1016/S0006-8993(99)01763-1] [PMID: 10517956]

[17] Szallasi A, Blumberg PM. Vanilloid (Capsaicin) receptors and mechanisms. Pharmacol Rev 1999; 51(2): 159-212. [PMID: 10353985]

[18] Karai L, Brown DC, Mannes AJ, et al. Deletion of vanilloid receptor 1-expressing primary afferent neurons for pain control. J Clin Invest 2004; 113(9): 1344-52. [http://dx.doi.org/10.1172/JCI20449] [PMID: 15124026]

[19] Brown DC, Iadarola MJ, Perkowski SZ, et al. Physiologic and antinociceptive effects of intrathecal resiniferatoxin in a canine bone cancer model. Anesthesiology 2005; 103(5): 1052-9. [http://dx.doi.org/10.1097/00000542-200511000-00020] [PMID: 16249680]

[20] Kissin EY, Freitas CF, Kissin I. The effects of intraarticular resiniferatoxin in experimental knee-joint arthritis. Anesth Analg 2005; 101(5): 1433-9. [http://dx.doi.org/10.1213/01.ANE.0000180998.29890.B0] [PMID: 16244007]

[21] Mishra SK, Hoon MA. Ablation of TrpV1 neurons reveals their selective role in thermal pain sensation. Mol Cell Neurosci 2010; 43(1): 157-63. [http://dx.doi.org/10.1016/j.mcn.2009.10.006] [PMID: 19853036]

[22] Bishnoi M, Bosgraaf CA, Abooj M, Zhong L, Premkumar LS. Streptozotocin-induced early thermal hyperalgesia is independent of glycemic state of rats: role of transient receptor potential vanilloid 1(TRPV1) and inflammatory mediators. Mol Pain 2011; 7: 52. a [http://dx.doi.org/10.1186/1744-8069-7-52] [PMID: 21794120]

[23] Bishnoi M, Bosgraaf CA, Premkumar LS. Preservation of acute pain and efferent functions following intrathecal resiniferatoxin-induced analgesia in rats. J Pain 2011; 12(9): 991-1003. b [http://dx.doi.org/10.1016/j.jpain.2011.03.005] [PMID: 21680254]

[24] Jeffry JA, Yu SQ, Sikand P, Parihar A, Evans MS, Premkumar LS. Selective targeting of TRPV1 expressing sensory nerve terminals in the spinal cord for long lasting analgesia. PLoS One 2009; 4(9): e7021. [http://dx.doi.org/10.1371/journal.pone.0007021] [PMID: 19753113]

[25] Raisinghani M, Pabbidi RM, Premkumar LS. Activation of transient receptor potential vanilloid 1 (TRPV1) by resiniferatoxin. J Physiol 2005; 567(Pt 3): 771-86. [http://dx.doi.org/10.1113/jphysiol.2005.087874] [PMID: 16037081]

[26] Iadarola MJ, Mannes AJ. The vanilloid agonist resiniferatoxin for interventional-based pain control. Curr Top Med Chem 2011; 11(17): 2171-9. [http://dx.doi.org/10.2174/156802611796904942] [PMID: 21671877]

[27] Mestre C, Pélissier T, Fialip J, Wilcox G, Eschalier A. A method to perform direct transcutaneous intrathecal injection in rats. J Pharmacol Toxicol Methods 1994; 32(4): 197-200. [http://dx.doi.org/10.1016/1056-8719(94)90087-6] [PMID: 7881133]

[28] Pabbidi RM, Cao DS, Parihar A, Pauza ME, Premkumar LS. Direct role of Streptozotocin in inducing thermal hyperalgesia by enhanced expression of TRPV1 in sensory neurons. Mol Pharmacol 2008; 73: 995-1004. [http://dx.doi.org/10.1124/mol.107.041707] [PMID: 18089839]

[29] Cavanaugh DJ, Chesler AT, Jackson AC, et al. Trpv1 reporter mice reveal highly restricted brain distribution and functional expression in arteriolar smooth muscle cells. J Neurosci 2011; 31(13): 5067-77. [http://dx.doi.org/10.1523/JNEUROSCI.6451-10.2011] [PMID: 21451044]

[30] Mishra SK, Tisel SM, Orestes P, Bhangoo SK, Hoon MA. TRPV1-lineage neurons are required for thermal sensation. EMBO J 2011; 30(3): 582-93. [http://dx.doi.org/10.1038/emboj.2010.325] [PMID: 21139565] 
[31] Kim YH, Back SK, Davies AJ, et al. TRPV1 in GABAergic interneurons mediates neuropathic mechanical allodynia and disinhibition of the nociceptive circuitry in the spinal cord. Neuron 2012; 74(4): 640-7. [http://dx.doi.org/10.1016/j.neuron.2012.02.039] [PMID: 22632722]

[32] Scherrer G, Imamachi N, Cao YQ, et al. Dissociation of the opioid receptor mechanisms that control mechanical and heat pain. Cell 2009; 137(6): 1148-59. [http://dx.doi.org/10.1016/j.cell.2009.04.019] [PMID: 19524516]

[33] Sikand P, Premkumar LS. Potentiation of glutamatergic synaptic transmission by protein kinase C-mediated sensitization of TRPV1 at the first sensory synapse. J Physiol 2007; 581(Pt 2): 631-47.

[http://dx.doi.org/10.1113/jphysiol.2006.118620] [PMID: 17363391]

[34] Gao YJ, Ji RR. Targeting astrocyte signaling for chronic pain. Neurotherapeutics 2010; 7(4): 482-93. [http://dx.doi.org/10.1016/j.nurt.2010.05.016] [PMID: 20880510]

[35] Kohno T. Neuropathic pain and neuron-glia interactions in the spinal cord. J Anesth 2010; 24(2): 325-7. [http://dx.doi.org/10.1007/s00540-010-0918-1] [PMID: 20237809]

[36] Ledeboer A, Sloane EM, Milligan ED, et al. Minocycline attenuates mechanical allodynia and proinflammatory cytokine expression in rat models of pain facilitation. Pain 2005; 115(1-2): 71-83.

[http://dx.doi.org/10.1016/j.pain.2005.02.009] [PMID: 15836971]

[37] Raghavendra V, Tanga F, DeLeo JA. Inhibition of microglial activation attenuates the development but not existing hypersensitivity in a rat model of neuropathy. J Pharmacol Exp Ther 2003; 306(2): 624-30. [http://dx.doi.org/10.1124/jpet.103.052407] [PMID: 12734393]

[38] Kim SR, Kim SU, Oh U, Jin BK. Transient receptor potential vanilloid subtype 1 mediates microglial cell death in vivo and in vitro via Ca2+mediated mitochondrial damage and cytochrome c release. J Immunol 2006; 177(7): 4322-9. [http://dx.doi.org/10.4049/jimmunol.177.7.4322] [PMID: 16982866]

[39] Lappin SC, Randall AD, Gunthorpe MJ, Morisset V. TRPV1 antagonist, SB-366791, inhibits glutamatergic synaptic transmission in rat spinal dorsal horn following peripheral inflammation. Eur J Pharmacol 2006; 540(1-3): 73-81. [http://dx.doi.org/10.1016/j.ejphar.2006.04.046] [PMID: 16737693]

[40] Premkumar LS. Targeting TRPV1 as an alternative approach to narcotic analgesics to treat chronic pain conditions. AAPS J 2010; 12(3): 361-70. [http://dx.doi.org/10.1208/s12248-010-9196-y] [PMID: 20440589]

[41] Spicarova D, Palecek J. Tumor necrosis factor alpha sensitizes spinal cord TRPV1 receptors to the endogenous agonist N-oleoyldopamine. J Neuroinflammation 2010; 7: 49.

[http://dx.doi.org/10.1186/1742-2094-7-49] [PMID: 20796308]

[42] Westlund KN, Kochukov MY, Lu Y, McNearney TA. Impact of central and peripheral TRPV1 and ROS levels on proinflammatory mediators and nociceptive behavior. Mol Pain 2010; 6: 46. [http://dx.doi.org/10.1186/1744-8069-6-46] [PMID: 20691059]

[43] Ji RR, Baba H, Brenner GJ, Woolf CJ. Nociceptive-specific activation of ERK in spinal neurons contributes to pain hypersensitivity. Nat Neurosci 1999; 2(12): 1114-9. [http://dx.doi.org/10.1038/16040] [PMID: 10570489]

[44] Ji RR, Befort K, Brenner GJ, Woolf CJ. ERK MAP kinase activation in superficial spinal cord neurons induces prodynorphin and NK-1 upregulation and contributes to persistent inflammatory pain hypersensitivity. J Neurosci 2002; 22(2): 478-85. a [PMID: 11784793]

[45] Ji RR, Samad TA, Jin SX, Schmoll R, Woolf CJ. p38 MAPK activation by NGF in primary sensory neurons after inflammation increases TRPV1 levels and maintains heat hyperalgesia. Neuron 2002; 36(1): 57-68. b [http://dx.doi.org/10.1016/S0896-6273(02)00908-X] [PMID: 12367506]

[46] Tsuda M, Mizokoshi A, Shigemoto-Mogami Y, Koizumi S, Inoue K. Activation of p38 mitogen-activated protein kinase in spinal hyperactive microglia contributes to pain hypersensitivity following peripheral nerve injury. Glia 2004; 45(1): 89-95. [http://dx.doi.org/10.1002/glia.10308] [PMID: 14648549]

[47] Zhuang ZY, Gerner P, Woolf CJ, Ji RR. ERK is sequentially activated in neurons, microglia, and astrocytes by spinal nerve ligation and contributes to mechanical allodynia in this neuropathic pain model. Pain 2005; 114(1-2): 149-59. [http://dx.doi.org/10.1016/j.pain.2004.12.022] [PMID: 15733640]

[48] Hains BC, Waxman SG. Activated microglia contribute to the maintenance of chronic pain after spinal cord injury. J Neurosci 2006; 26(16): 4308-17. [http://dx.doi.org/10.1523/JNEUROSCI.0003-06.2006] [PMID: 16624951]

[49] Ji RR, Woolf CJ. Neuronal plasticity and signal transduction in nociceptive neurons: implications for the initiation and maintenance of pathological pain. Neurobiol Dis 2001; 8(1): 1-10. [http://dx.doi.org/10.1006/nbdi.2000.0360] [PMID: 11162235]

[50] Lever IJ, Bradbury EJ, Cunningham JR, et al. Brain-derived neurotrophic factor is released in the dorsal horn by distinctive patterns of afferent fiber stimulation. J Neurosci 2001; 21(12): 4469-77. 
[PMID: 11404434]

[51] Lever IJ, Pezet S, McMahon SB, Malcangio M. The signaling components of sensory fiber transmission involved in the activation of ERK MAP kinase in the mouse dorsal horn. Mol Cell Neurosci 2003; 24(2): 259-70. [http://dx.doi.org/10.1016/S1044-7431(03)00200-8] [PMID: 14572451]

[52] Ji RR, Gereau RW IV, Malcangio M, Strichartz GR. MAP kinase and pain. Brain Res Rev 2009; 60(1): 135-48. [http://dx.doi.org/10.1016/j.brainresrev.2008.12.011] [PMID: 19150373]

[53] Yang K, Kumamoto E, Furue H, Yoshimura M. Capsaicin facilitates excitatory but not inhibitory synaptic transmission in substantia gelatinosa of the rat spinal cord. Neurosci Lett 1998; 255(3): 135-8. [http://dx.doi.org/10.1016/S0304-3940(98)00730-7] [PMID: 9832191]

[54] Nakatsuka T, Furue H, Yoshimura M, Gu JG. Activation of central terminal vanilloid receptor-1 receptors and alpha beta-methylene-ATPsensitive P2X receptors reveals a converged synaptic activity onto the deep dorsal horn neurons of the spinal cord. J Neurosci 2002; 22(4): 1228-37.

[PMID: 11850450]

[55] Baccei ML, Bardoni R, Fitzgerald M. Development of nociceptive synaptic inputs to the neonatal rat dorsal horn: glutamate release by capsaicin and menthol. J Physiol 2003; 549(Pt 1): 231-42. [http://dx.doi.org/10.1113/jphysiol.2003.040451] [PMID: 12679376]

[56] Morton CR, Hutchison WD. Release of sensory neuropeptides in the spinal cord: studies with calcitonin gene-related peptide and galanin. Neuroscience 1989; 31(3): 807-15. [http://dx.doi.org/10.1016/0306-4522(89)90443-0] [PMID: 2480554]

[57] Schaible HG. On the role of tachykinins and calcitonin gene-related peptide in the spinal mechanisms of nociception and in the induction and maintenance of inflammation-evoked hyperexcitability in spinal cord neurons (with special reference to nociception in joints). Prog Brain Res 1996; 113: 423-41.

[http://dx.doi.org/10.1016/S0079-6123(08)61102-4] [PMID: 9009749]

[58] Galeazza MT, Garry MG, Yost HJ, Strait KA, Hargreaves KM, Seybold VS. Plasticity in the synthesis and storage of substance P and calcitonin gene-related peptide in primary afferent neurons during peripheral inflammation. Neuroscience 1995; 66(2): 443-58. [http://dx.doi.org/10.1016/0306-4522(94)00545-G] [PMID: 7477885]

[59] Neugebauer V, Rümenapp P, Schaible HG. Calcitonin gene-related peptide is involved in the spinal processing of mechanosensory input from the rat's knee joint and in the generation and maintenance of hyperexcitability of dorsal horn-neurons during development of acute inflammation. Neuroscience 1996; 71(4): 1095-109.

[http://dx.doi.org/10.1016/0306-4522(95)00473-4] [PMID: 8684614]

[60] Han JS, Li W, Neugebauer V. Critical role of calcitonin gene-related peptide 1 receptors in the amygdala in synaptic plasticity and pain behavior. J Neurosci 2005; 25(46): 10717-28.

[http://dx.doi.org/10.1523/JNEUROSCI.4112-05.2005] [PMID: 16291945]

[61] Wong GY, Gavva NR. Therapeutic potential of vanilloid receptor TRPV1 agonists and antagonists as analgesics: Recent advances and setbacks. Brain Res Rev 2009; 60(1): 267-77. [http://dx.doi.org/10.1016/j.brainresrev.2008.12.006] [PMID: 19150372]

[62] Tang L, Chen Y, Chen Z, Blumberg PM, Kozikowski AP, Wang ZJ. Antinociceptive pharmacology of N-(4-chlorobenzyl)-N'-(4-hydroxy-3iodo-5-methoxybenzyl) thiourea, a high-affinity competitive antagonist of the transient receptor potential vanilloid 1 receptor. J Pharmacol Exp Ther 2007; 321(2): 791-8. [http://dx.doi.org/10.1124/jpet.106.117572] [PMID: 17312187]

[63] Kanai Y, Hara T, Imai A, Sakakibara A. Differential involvement of TRPV1 receptors at the central and peripheral nerves in CFA-induced mechanical and thermal hyperalgesia. J Pharm Pharmacol 2007; 59(5): 733-8. [http://dx.doi.org/10.1211/jpp.59.5.0015] [PMID: 17524240]

[64] Patwardhan AM, Scotland PE, Akopian AN, Hargreaves KM. Activation of TRPV1 in the spinal cord by oxidized linoleic acid metabolites contributes to inflammatory hyperalgesia. Proc Natl Acad Sci USA 2009; 106(44): 18820-4. [http://dx.doi.org/10.1073/pnas.0905415106] [PMID: 19843694]

[65] Zhang F, Yang H, Wang Z, et al. Transient receptor potential vanilloid 1 activation induces inflammatory cytokine release in corneal epithelium through MAPK signaling. J Cell Physiol 2007; 213(3): 730-9. [http://dx.doi.org/10.1002/jcp.21141] [PMID: 17508360]

[66] Strecker T, Reeh PW, Weyand M, Messlinger K. Release of calcitonin gene-related peptide from the isolated mouse heart: methodological validation of a new model. Neuropeptides 2006; 40(2): 107-13. [http://dx.doi.org/10.1016/j.npep.2005.11.005] [PMID: 16413055]

Received: March 31, $2015 \quad$ Revised: November 20, 2015 Accepted: November 24, 2015

(C) Abooj et al.; Licensee Bentham Open.

This is an open access article licensed under the terms of the Creative Commons Attribution-Non-Commercial 4.0 International Public License (CC BY-NC 4.0) (https://creativecommons.org/licenses/by-nc/4.0/legalcode), which permits unrestricted, non-commercial use, distribution and reproduction in any medium, provided the work is properly cited. 